\title{
Cultural Use of Turtle Shells, an Underrated Threat in Turtle Conservation: A Case Study in Assam, India
}

\author{
Gaurav Barhadiya ${ }^{1}$ and Shailendra Singh ${ }^{2}$
}

${ }^{1}$ Department of Environmental Studies, University of Delhi, New Delhi, Delhi-110007, India (Gaurav7wild7@gmail.com)

${ }^{2}$ Turtle Survival Alliance-India, Wildlife Conservation Society, Lucknow, Uttar Pradesh-226021, India

$S^{i}$ ixty-one percent of the 356 extant species of turtles are threatened or extinct (Lovich et al. 2018). Asian turtles have the highest percentages of imperiled species $(75.0 \%$ Critically Endangered [CR] + Endangered [EN], 83.0\% Threatened) due to high levels of exploitation (Rhodin et al. 2018). India is home to 29 species of freshwater turtles and tortoises, of which 21 species have been recorded in northeastern India and 20 from Assam (Ahmed et al. 2009; Purkayastha 2013). Most of the ethnic groups in the region consume turtle meat and eggs. Furthermore, turtle shells and meat are used for various traditional, cultural, and religious practices (Das et al. 2012).

As part of a recent (February-July 2019) study in northeastern India, an intensive questionnaire was used to survey 200 households in five villages (Jia Bharali, $26.710563^{\circ} \mathrm{N}$, $92.852261^{\circ} \mathrm{E}$; Biswanath Ghat, $26.659634^{\circ} \mathrm{N}, 93.166677^{\circ} \mathrm{E}$; Batiamari Centre, $26.783616^{\circ} \mathrm{N}, 93.415533^{\circ} \mathrm{E}$; Gohpur, $26.8789602^{\circ} \mathrm{N}, 93.6057847^{\circ} \mathrm{E}$; and Major Sapori $\left(26.905351^{\circ} \mathrm{N}, 93.897993^{\circ} \mathrm{E}\right)$ near the Brahmaputra River in Assam (Fig. 1). The questionnaires addressed people's traditional knowledge of turtles. We conducted structured interviews, asking questions related to turtles while showing participating villagers printed placards with photographs of turtles known to occur in the region. We also made inquiries regarding turtle shells or live turtles kept in households as trophies or for other purposes. No previous surveys of this type had been conducted in the chosen villages. We identified all turtles and turtle shells using descriptions in Smith (1931) and Purkayastha (2013). We extracted the current conservation status for all species encountered from the IUCN Red List of Threatened Species (IUCN 2020) and the Indian Wildlife Protection Act (1972).

We encountered 27 turtle shells belonging to two families and five species (Table 1; Fig. 2): Indian Roofed Turtle, Pangshura tecta (Gray 1830); Indian Tent Turtle, Pangshura tentoria (Gray 1834); Tricarinate Hill Turtle, Melanochelys tricarinata (Blyth 1856); Indian Peacock Soft-shelled Turtle, Nilssonia hurum (Gray 1830), and the Ganges Soft-shelled Turtle, Nilssonia gangetica (Cuvier 1825). We also recorded two live Ganges Soft-shelled Turtles and one Indian Peacock Soft-shelled Turtle from two houses. Most of the turtle shells were hanging in cowsheds, but some were kept inside houses. Many of the villagers believe that a turtle shell kept in a cowshed will protect cattle from disease and bring prosperity to the family of the shell keeper.

Many ethnic groups associate turtles with healing, wisdom, and spirituality (Hassan and Sadek 2015), and turtle shells and

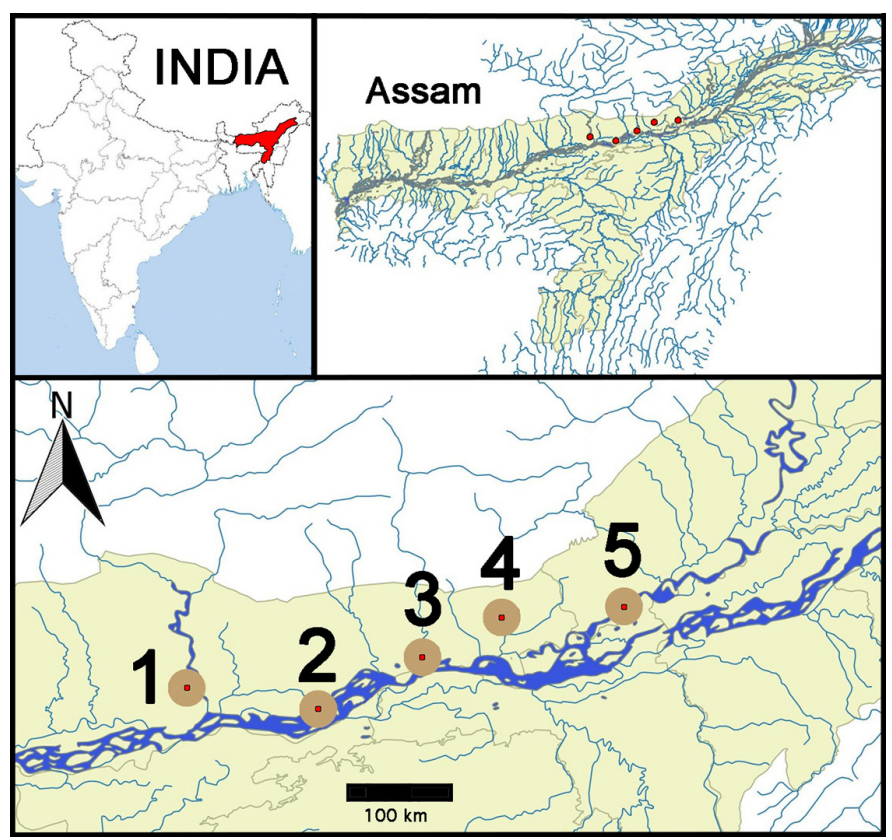

Fig. 1. Map showing locations of surveyed villages near the Brahmaputra River in Assam: (1) Jia Bharali, (2) Biswanath, (3) Batiamari Centre, (4) Gohpur, and (5) Major Chapori. 
Table 1. Turtle shells found in various households in surveyed Assam villages. IUCN = International Union for Conservation of Nature, WPA = Indian Wildlife Protection Act (1972), LC = Least Concerned, $\mathrm{VU}=$ Vulnerable, $\mathrm{Sc}=$ Schedule.

\begin{tabular}{lcc} 
Species (n) & $\begin{array}{r}\text { IUCN } \\
\text { Status }\end{array}$ & $\begin{array}{r}\text { WPA } \\
\text { Status }\end{array}$ \\
\hline Geomydidae & & \\
\hline Indian Roofed Turtle (Pangshura tecta) (9) & LC & Sc I \\
\hline Indian Tent Turtle (Pangshura tentoria) (12) & LC & Sc I \\
\hline Tricarinate Hill Turtle (Melanochelys tricarinata) (2) & VU & Sc I \\
\hline
\end{tabular}

\section{Trionychidae}

\begin{tabular}{lll}
\hline Indian Peacock Soft-shelled Turtle (Nilssonia hurum) (3) & VU & Sc I \\
\hline Ganges Soft-shelled Turtle (Nilssonia gangetica) (1) & VU & Sc I
\end{tabular}

various body parts are used in zootherapy in many regions of the world (e.g., Costa-Neto 1999). Observations similar to ours were recorded by Khatum et al. (2013) in Bangladesh, where turtle shells are used to cure infections on cattle legs. Mahavar and Jaroli (2007) stated that the ash from burning turtles shells is used to cure skin burns and for the treatment of asthma and tuberculosis in Rajasthan, India. Although little information exists regarding the extent of using turtles or their parts for zootherapy in India, the practice of exploiting turtle shells and body parts for zootherapy could pose a considerable challenge for the conservation of Indian turtles. Increasing the awareness of nature, the importance of turtles to ecosystems, and the enactment and enforcement of legislation among relevant stakeholders, especially young people, is an urgent need if Indian turtles are to remain a part of India's future.

\section{Acknowledgements}

We thank the Turtle Survival Alliance (TSA) and the Disney Conservation Fund for financial support and the Wildlife Conservation Society-India for logistical support. This study was conducted under PCCF (Wildlife) Assam research permit WL/FG.31/Pt/Technical Committee 2018 (19 May 2018) and Office Order No. 97 (16 July 2018). We also thank Divisional Forest Officer Mr. Suhas Kadam and Dr. P.C. Ray, TSA Project Coordinator for North-east India, for logistical support.

\section{Literature Cited}

Ahmed, M.F., A. Das, and S.K. Dutta. 2009. Amphibians and Reptiles of Northeast India. A Photographic Guide. Aaranyak, Guwahati, India.

Costa-Neto, E.M. 1999. Healing with animals in Feira de Santana city, Bahia, Brazil. Journal of Ethnopharmacology 65: 225-230.

Das, K.C., S. Kundu, S.K. Ghosh, and A. Gupta. 2012. Traditional knowledge on zootherapeutic uses of turtle is an issue for international conservation, pp. 81-89. In: K.B. Singh and K. Lalchhandama (eds.), Recent Advances in Natural Products Research. Proceedings of the National Seminar RANPR 2012 at Seminar Hall, Live Science Building, Pachhunga University College, Aizawl 796001, Mizoram, India. Mizo Post Graduate Science Society (MIPOGRASS) in partnership with Regional Institute of Paramedical and Nursing Sciences (RIPANS), Aizawl, India.

Hassan, A.E.S. and S. Sadek. 2015. Animal symbolism in Indian American poetry. European Scientific Journal 11(11): 61-81.

Khatun, Z., P. Bhuiyan, M.S.I. Roney, and M. Rahmatullah. 2013. Traditional knowledge on zootherapeutic practices among some folk medicinal practitioners of Bangladesh. American-Eurasian Journal of Sustainable Agriculture 7(3): $155-161$.

Lovich, J.E., J.R. Ennen, M. Agha, and J.W. Gibbons. 2018. Where have all the turtles gone, and why does it matter? Bioscience 68: 771-781.

Mahawar, M.M. and D.P. Jaroli. 2007. Traditional knowledge on zootherapeutic uses by the Saharia tribe of Rajasthan, India. Journal of Ethnobiology and Ethnomedicine 3: 25.

Purkayastha, J. 2013. An Amateur's Guide to Reptiles of Assam. EBH Publisher, Guwahati, India.

Rhodin, A.G., C.B. Stanford, P.P. Van Dijk, C. Eisemberg, L. Luiselli, R.A.
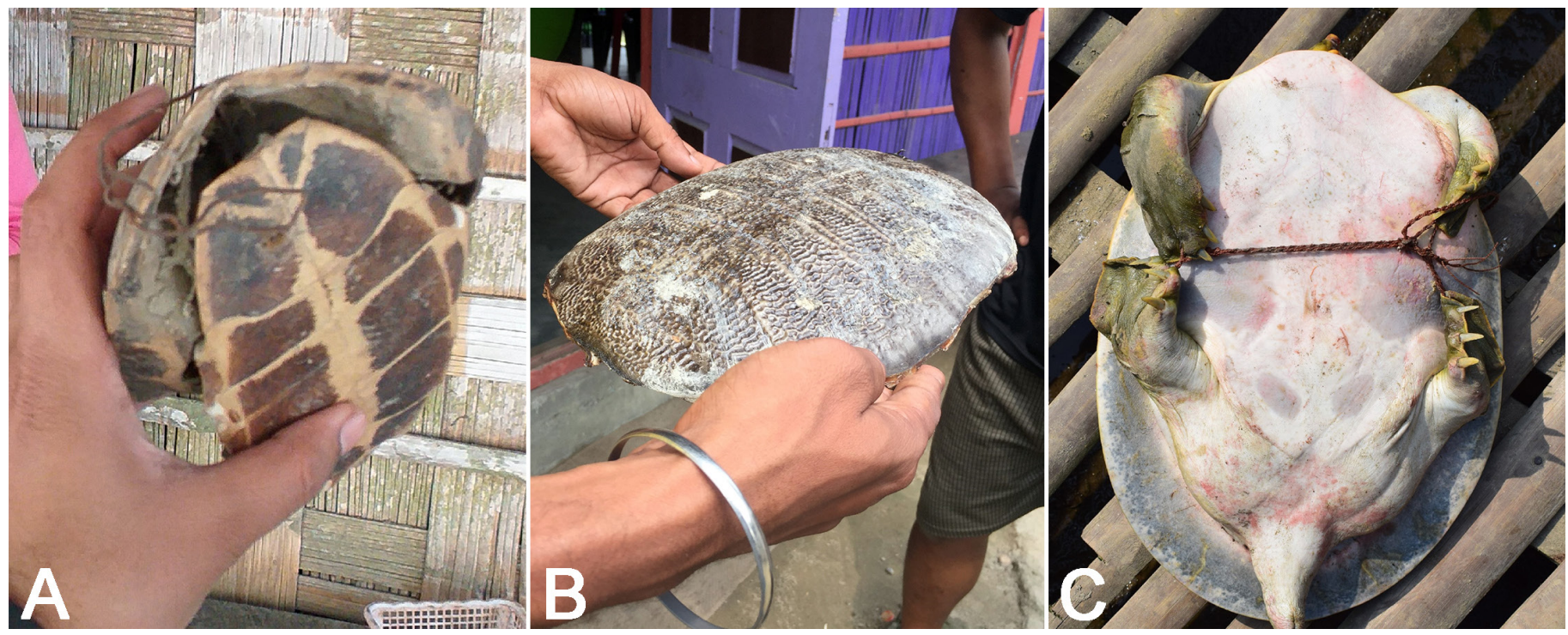

Fig. 2. Shells and a live turtle found in households in surveyed villages near the Brahmaputra River in Assam: (A) Shell of an Indian Tent Turtle (Pangshura tentoria); (B) shell of an Indian Peacock Soft-shelled Turtle (Nilssonia hurum); (C) a live Ganges Soft-shelled Turtle (Nilssonia gangetica). Photographs by the author. 
Mittermeier, R. Hudson, B.D. Horne, E.V. Goode, G. Kuchling, A. Walde, E.H.W. Baard, K.H. Berry, A. Bertolero, T.E.G. Blanck, R. Bour, K.A. Buhlmann, L.J. Cayot, S. Collett, A. Currylow, I. Das, T. Diagne, J.R. Ennen, G. Forero-Medina, M.G. Frankel, U. Fritz, G. García, J.W. Gibbons, P.M. Gibbons, G. Shiping, J. Guntoro, M.D. Hofmeyr, J.B. Iverson, A.R. Kiester, M. Lau, D.P. Lawson, J.E. Lovich, E.O. Moll, V.P. Páez, R. Palomo-Ramos, K.Platt, S.G. Platt, P.C.H. Pritchard, H.R. Quinn, S.C. Rahman, S.T. Randrianjafizanaka, J. Schaffer, W. Selman, H.B. Shaffer, D.S.K. Sharma,
S. Haitao, S. Singh, R. Spencer K. Stannard, S. Sutcliffe, S. Thomson, and R.C. Vogt. 2018. Global conservation status of turtles and tortoises (order Testudines). Chelonian Conservation and Biology 17: 135-161.

Smith, M.A. 1931. The Fauna of British India, Including Ceylon and Burma. Reptilia and Amphibia Volume I.-Loricata, Testudines. Taylor and Francis, London, England.

IUCN (International Union for Conservation of Nature). 2020. The IUCN Red List of Threatened Species. Version 2020-1. <https://www.iucnredlist.org>. 